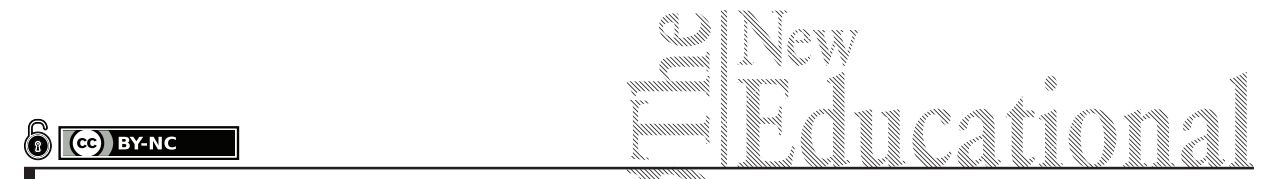

Liudmyla Sydorivna Brovchak, Lesia Vay livn Staro Larysa Mykolaivna Likhitska

Ukraine

\title{
Pedagogical Conditions for Creative and Artistic Development of Children of Senior Preschool Age by Means of Art
}

DOI: 10.15804/tner.2018.52.2.16

\begin{abstract}
The paper highlights the problem of creative and artistic development of preschoolers by means of art. The place and role of art in the creative and artistic development of children of senior preschool age are determined. The content and peculiarities of the creative and artistic development of children in the process of educational activity by means of art are revealed. The pedagogical conditions for the creative and artistic development of preschool children in the process of artistic activity are singled out on the basis of analyzed modern concepts. On the basis of pedagogical conditions, a model of creative and artistic development of children of senior preschool age by means of art is designed. Researchers reveal in children of the senior preschool age the dynamics of creative and artistic development and the degree of the development of the investigated qualities in children of the control and experimental groups is analyzed. The necessity of searching for rational ways and precisely specifying the mechanism of using art in the process of creative and artistic development of children of the senior preschool age is emphasized.
\end{abstract}

Keywords: development, creative and artistic development, art, senior preschool age, pedagogical conditions 


\section{Introduction}

In modern pedagogical research connected with the problem of improving the functioning of the pedagogical system, increasing the efficiency of the educational process, there is an important task is to identify, justify and test the pedagogical conditions that ensure the success of educational activities. From the pedagogical point of view, preschool age is a favorable period for the development of creative and artistic abilities because at this age the child realizes the relationship between themselves and the outside world for the first time. The use of works of art in the educational process is a significant contribution to the formation of the moral and aesthetic worldview of children of preschool age.

Analysis of pedagogical and methodological literature shows that in the practice of preschool education the problem of using works of art in classes in pre-school establishments has repeatedly been investigated. In today's conditions of social development, complicated by the spread of destructive, destabilizing tendencies in Ukraine, the cultural role of art grows to a large extent, and the scope of its aesthetic functioning is expanding. At the same time, there arise new problems related with the necessity to improve the content and forms of the introduction of art study disciplines in the educational process of educational institutions of Ukraine. Nowadays, teachers do not pay enough attention to works of art, and in our opinion, it is a problem because what we do through art is form in children the love of beauty and create a respectful attitude to folk traditions.

The purpose of the paper is to consider the influence of pedagogical conditions on the dynamics of the child's creative and artistic development by means of art. The tasks of the paper include the separation of pedagogical conditions for the artistic and creative development of children by means of art and the presentation of a model of artistic and creative development by means of art, the discovery of dynamics of artistic and creative development among children of the senior preschool age by means of testing and performing creative work, comparing the degree of development of the studied qualities in children of the control and experimental groups, comparing the results of the current and the final tests.

\section{$\underline{\text { Research Methodology }}$}

With the orientation on the mentioned theoretical tasks and in order to assess the degree of the artistic and creative development of children, we conducted the experimental work. For the experimental research, 756 children of the senior 
preschool age were involved (376 - control group, 380 - experimental group). We offered creative tasks aimed at artistic and creative thinking and predicted the discovery of the level of individual indicators of the artistic and creative development of children. To obtain objective data, we used the method of analyzing the products of creative activity of students and the method of generalization of independent characteristics. In order to find out the existence of a significant difference in the results of the experimental and control groups, i.e., the effect of the developed methodology, and not the influence of random factors, the criterion of Pearson's chi-squared test was used.

\section{Research Results}

Organization of special pedagogical conditions is a methodologically grounded organization of the educational space, which defines all components of the educational process. In the effective pedagogical conditions for the artistic and creative development of the child by means of art we included: orientation of the educational process for the acquisition of children's artistic and aesthetic values of art, actualization of the educational potential of works of art in the process of the artistic and creative activity of the child, involvement of preschoolers in various types of artistic and creative activity, and systematic influence of works of art on the formation of the intellectual, emotional and axiological components of the child's consciousness.

The focus of the educational process on children's acquisition of artistic and aesthetic values of art should be within the aesthetic cycle through preschoolers' gradual acquisition of artistic and aesthetic experience, in particular, mastering artistic knowledge and ideas and skills to delve into the perception of the emotional and artistic-figurative content of the work. The main thing in this process is to make children focus on the value-significant components of the artistic work, the formation of awareness that the work of art is self-sufficient; the ultimate artistic meaning of it with the greatest completeness is contained only in it itself, in its artistic form and disclosed only in the process of its perception. Since this content is realized by the author according to the laws of this kind of art, artistic qualities become valuable and significant: harmony, expressiveness and imaginativeness of the language, proportionality, symmetry, rhythm, etc. In its combination of the creation of an artistic image, the work of art in the unity of its content and form embodies a certain artistic and aesthetic value, expressed by artistic means. The important thing in this process is the child's communication with the best 
examples of Ukrainian heritage of high artistic value, formation of landmarks, standards, criteria of evaluation of artistic works.

Updating the educational potential of works of art in the process of the child's artistic and creative activity involves emphasizing the teacher's attention to the identification and implementation of the educational potential of artistic material of various types of art, which will strengthen the developing essence of the artistic and creative cycle.

One of the integrators of artistic content can be a common theme, i.e., the discovery of common themes embodied in the works of various types of art, which will help to consider similar material simultaneously from different sides, with the help of various artistic means. The following areas may be: "Nature in Embroidery", "The Breath of Pottery", "Art in Everyday Life", "Fairy-Tale Mood in Vytinanka (Papercutting)", "Fantastic Motifs in Decorative And Applied Art", "The Dance in The Workshop of the Blacksmith", "Bright Colors of Music", "Melody of Poetry," etc. Using them we will have an opportunity to reveal the value of each type of art, being in a single thematic space, to reveal universal human and artistic-aesthetic values embodied in works of various types of art, to expand the range of children's artistic interests, to form their associative thinking, etc.

Involving preschool children in various types of artistic and creative activity. Children in the establishments of preschool education perceive not only knowledge of the surrounding world and ways of mastering this world, but also certain ways of human behavior, their relationship, understanding what is good, and what is bad, what is beautiful, and what is ugly, etc. Thus, preschoolers are involved in moral, aesthetic and other types of human experience. Any kind of social experience is assimilated through activities that are adequate to this experience. You cannot learn how to draw or to sing, without doing certain exercises, and it is impossible to become a good person without doing good deeds. Therefore, it is important that the child's activities have a personal meaning for them, coincided with their point of view - have become an indicative basis for the actions to be performed. The personal acceptance of the indicative basis of the actions performed is a specific feature of the assimilation of any social (including artistic) experience (Krasoń, 2016).

Ensuring the purposeful and systematic influence of art on the formation of the intellectual, emotional and axiological components of the child's consciousness. An active attitude to reality in the process of its reflection is manifested not only in the selective attitude to the events and phenomena of the world, but also in the selection and use of those rich artistic means possessed by art. Art for children should be rich, diverse in content, in the sense that it creates, as well as in artistic 
expressiveness. Homogeneity of subjects, genres and methods of performance hampers the child's general and essential development.

Children are characterized by an active attitude to events. One can observe that some preschoolers "sound" depicted actions while drawing. Children's passion for the content of their drawings, active discovery of a personal attitude to the characters being depicted - all these facts make children's work more expressive. It is no coincidence that many painters turn to child creativity as an inexhaustible source of sincerity, immediacy, and artistic expression.

The unity of children's aesthetic knowledge and artistic practice on the material of art is fundamentally important, and first and foremost, such methodological techniques are developed that stimulate children's creative creation of independent compositions, rather than copying techniques of art. Selection of works of art in the process of studying art should be based on a well thought-out system of methodological techniques.

Therefore, for the effective organization of the educational process of preschoolers and for the creation of an artistic cycle in which the transformation of the child's personality traits and raising their level of artistic and creative abilities during the pedagogical interaction will require the implementation of pedagogical conditions aimed at the effective use of art in the process of artistic and creative development of children of senior preschool age. For the effective implementation of these pedagogical conditions, it is necessary to clearly identify ways of implementing the educational and developing potential of art in working with preschoolers.

In accordance with the determined pedagogical conditions, a model of artistic and creative development of children of the senior preschool age was developed by means of art, which is presented in Figure 1.

\section{Discussion}

To identify the dynamics of artistic and creative development, a control test was made which allowed for quantitative expressions of qualitative changes in the state of artistic and creative development of preschool children that took place under the influence of the introduced pedagogical conditions and the developed method of artistic and creative development of children in the process of familiarizing with works of art.

The tests were administered to the experimental and control groups, which covered 756 children of the senior preschool age. Allocation of the preschool children to the experimental (EG) and control (CG) groups was carried out on the basis of 


\begin{tabular}{|c|c|c|c|c|c|}
\hline \multicolumn{6}{|c|}{ Artistic and creative development of preschoolers by means of art } \\
\hline \multicolumn{6}{|c|}{ Components of artistic and creative development of children by means of art } \\
\hline Bioenergy & \multicolumn{2}{|c|}{ Artistic and aesthetic } & \multicolumn{2}{|c|}{$\begin{array}{c}\text { Cognitive- } \\
\text {-informational }\end{array}$} & $\begin{array}{l}\text { Emotional- } \\
\text {-axiological }\end{array}$ \\
\hline $\begin{array}{l}\text { health status } \\
\text { physical energy } \\
\text { artistic makings } \\
\text { creativity }\end{array}$ & \multicolumn{2}{|c|}{$\begin{array}{l}\text { aesthetic sensation } \\
\text { aesthetic experiences } \\
\text { artistic-figurative perception } \\
\text { tactile feeling }\end{array}$} & \multicolumn{2}{|c|}{$\begin{array}{l}\text { artistic thinking } \\
\text { visual assessment } \\
\text { artistic and creative skills }\end{array}$} & $\begin{array}{l}\text { creative work on the artistic } \\
\text { image, the need for artistic and } \\
\text { creative activity creativity, } \\
\text { independence, initiative }\end{array}$ \\
\hline \multicolumn{6}{|c|}{ Pedagogical conditions for artistic and creative development of preschool children by means of art } \\
\hline $\begin{array}{l}\text { direction of the } \\
\text { educational process for the } \\
\text { acquisition of artistic and } \\
\text { aesthetic values of art by } \\
\text { children }\end{array}$ & \multicolumn{2}{|c|}{$\begin{array}{l}\text { actualization of the educa- } \\
\text { tional potential of works of art } \\
\text { in the process of artistic and } \\
\text { creative activity of the child }\end{array}$} & \multicolumn{2}{|c|}{$\begin{array}{l}\text { involvement of preschoolers } \\
\text { in various types of artistic } \\
\text { and creative activity }\end{array}$} & $\begin{array}{l}\text { ensuring the purposeful and } \\
\text { systematic influence of works } \\
\text { of art on the formation of the } \\
\text { intellectual, emotional and } \\
\text { axiological components of the } \\
\text { child's consciousness }\end{array}$ \\
\hline \multicolumn{6}{|c|}{ The task of artistic and creative development of children by means of art } \\
\hline \multicolumn{2}{|l|}{ cognitive } & \multicolumn{2}{|c|}{ developing } & & educating \\
\hline \multicolumn{2}{|c|}{$\begin{array}{l}\text { aimed at expanding knowledge about } \\
\text { different types of art, its means, expres- } \\
\text { siveness, symbolism, etc. }\end{array}$} & \multicolumn{2}{|c|}{$\begin{array}{l}\text { Prediction of the child's psychological, } \\
\text { artistic and creative development by } \\
\text { obtaining knowledge about different } \\
\text { types of art and mastering elementary } \\
\text { practical skills and abilities }\end{array}$} & \multicolumn{2}{|c|}{$\begin{array}{l}\text { determining the formation of interest in } \\
\text { art, a careful attitude to artistic works as } \\
\text { a result of human activity, education of } \\
\text { culture and aesthetics of labor, positive } \\
\text { moral qualities }\end{array}$} \\
\hline
\end{tabular}

Figure 1. Model of artistic and creative development of children of the senior preschool age by means of art

the results of the final stage of the experiment; the experimental group included 380 children, the control one -376 children.

Analysis of the tasks performed to reveal the level of emotional-axiological attitude to works of art and their interaction, revealing the preschoolers' capability of emotional "immersion" in the figurative content of the work of art, showed that the children from the EG quite freely identify the emotional load of the work of art: they get the verbal characteristics of the emotional states embodied in the works of various types of folk art (48.2\%), determine the artistic qualities of the work of art, combine works of various types of art in accordance with emotional state, transmit emotions through various artistic means, in particular in color, forms, with some of them (35.8\%) doing it independently without the help of the teacher. This testifies to the preschoolers' understanding of emotions evoked by the piece of art (regardless of the type of folk art) and their awareness of their own emotional attitude. At the same time, the children from the CG also quite freely 
found the corresponding verbal characteristics of the emotional content of the work of art, but this concerned mostly well-known works of art.

The results of the study according to the emotional-axiological criterion are presented in the Chart 1.

Chart 1. Levels of children's artistic and creative development in accordance with the emotional and axiological criterion

\begin{tabular}{lcccccc}
\hline \multirow{2}{*}{ Markers } & \multicolumn{6}{c}{ Levels } \\
\cline { 2 - 7 } & \multicolumn{2}{c}{$\begin{array}{c}\text { Low } \\
\text { (EG/CG) }\end{array}$} & \multicolumn{2}{c}{$\begin{array}{c}\text { Mid } \\
\text { (EG/CG) }\end{array}$} & \multicolumn{2}{c}{$\begin{array}{c}\text { High } \\
\text { (EG/CG) }\end{array}$} \\
\cline { 2 - 7 } & $\%$ & $\%$ & $\%$ & $\%$ & $\%$ & $\%$ \\
\hline $\begin{array}{l}\text { Interest in different types of } \\
\text { art and their interaction }\end{array}$ & 1.8 & 6.6 & 68.6 & 67.8 & 29.6 & 25.6 \\
\hline $\begin{array}{l}\text { Emotional-axiological } \\
\text { attitude to art }\end{array}$ & 14.4 & 42.2 & 53.5 & 44.8 & 32.1 & 12.9 \\
\hline $\begin{array}{l}\text { Generalized } \\
\text { indicator }\end{array}$ & 8.95 & 24.4 & 66.1 & 56.3 & 25.9 & 19.3 \\
\hline
\end{tabular}

Diagnosis in accordance with the cognitive-associative criterion was carried out according to tasks similar to the stage of the experiment. Analysis of the results of the study showed that there were qualitative changes in the preschoolers from the EG on the formation of a sufficient artistic thesaurus (according to age) from different types of folk art; they are capable of characterizing artistic images created by different artistic languages, comparing them, revealing concepts, coordinating in different arts and giving characterization. At the same time, the children revealed mostly average (46.7\%) and low (39.2\%) levels of artistic and creative knowledge and representations, which was characterized by a sufficient vocabulary of artistic terminology; the presence of characteristics of artistic images in art. During the control test, the indicator of high and average levels of artistic and creative knowledge and representations of the preschoolers from the EG significantly increased compared with the children from the CG (average: by $64.5 \%$ of the children of the EG - by $46.7 \%$ of the children from the CG, high: by $22.4 \%$ of the children from the EG - by $14.2 \%$ of the children from the CG). Analysis of the diagnosis of the presence in the preschoolers of the ability to associate art testified to the active development of associative thinking in the children from the EG. Qualitative changes in the possibility to make association were expressed in the ability to independently establish artistic associations, to make analogies between different forms of art in the process of perception and creation of artistic images 
(24.2\% - high level, $66.6 \%$ - average). The children from the CG revealed mainly average and low levels of artistic association ability, a vast majority of them tried to make artistic associations, to conduct analogies between images and means of different types of art only with the help of the educator. The results of the study by the cognitive-associative criterion are presented in Chart 2.

Chart 2. Levels of artistic and creative development of children of senior preschool age in accordance with the cognitive-associative criterion

\begin{tabular}{lcccccc}
\hline \multirow{2}{*}{ Markers } & \multicolumn{6}{c}{ Levels } \\
\cline { 2 - 7 } & \multicolumn{2}{c}{$\begin{array}{c}\text { Low } \\
\text { (EG/CG) }\end{array}$} & \multicolumn{2}{c}{$\begin{array}{c}\text { Mid } \\
\text { (EG/CG) }\end{array}$} & \multicolumn{2}{c}{$\begin{array}{c}\text { High } \\
\text { (EG/CG) }\end{array}$} \\
\cline { 2 - 7 } & $\%$ & $\%$ & $\%$ & $\%$ & $\%$ & $\%$ \\
\hline $\begin{array}{l}\text { Artistic and creative } \\
\text { erudition }\end{array}$ & 13.2 & 39.2 & 64.5 & 46.7 & 22.4 & 14.2 \\
\hline $\begin{array}{l}\text { Ability to make artistic } \\
\text { associations }\end{array}$ & 9.5 & 25.8 & 66.6 & 64.6 & 24.2 & 9.8 \\
\hline $\begin{array}{l}\text { Generalized } \\
\text { indicator }\end{array}$ & 11.4 & 32.5 & 65.6 & 55.7 & 23.3 & 12.0 \\
\hline
\end{tabular}

Identification of levels of the artistic and creative development of children of the senior preschool age by the creative-operating criterion was carried out according to tasks which were similar to the tasks of the final stage of the experiment.

Analysis of the results showed that the preschool children have certain artistic and creative skills (26.8\% of the children have high and $65.1 \%$ average level) compared to the children from the CG (9.7\% - high, 54.2\% - average): they independently choose the means of expressiveness of one of the types of art for the implementation of artistic images, are capable of artistic interpretation of the image from one language to another (e.g., to stage, "to voice" a work of decorative and applied arts, to create illustrations to a literary or musical work, etc.). At the same time, the children from the CG mostly have average and low levels of artistic and creative skills, performing similar tasks subject to preliminary discussion with the teacher, or according to the proposed model.

Pedagogical observation confirmed the positive dynamics of the levels of the artistic and creative development of the preschool children from the EG: these children at the end of the study showed great creative activity in class compared to the children from the CG $(21.6 \%$ of the children from the EG and $14.4 \%$ of the children from the CG) and in comparison with the final stage of the experiment, where the high level was only $3.2 \%$. After the control test, it was ascertained that 
$45.6 \%$ of the children of the senior preschool age show initiative to independently create an artistic image, choose the means of its artistic embodiment, offer the embodiment of images using various means, their own variants how to stage works, etc. It is noted that $68.9 \%$ of the children from the CG also show an active desire to create artistic images, but using the means of only one type of folk art, in the form of artistic activity they captured better. The results of the study on the creative-operating criterion are highlighted in Chart 3.

Chart 3. Levels of artistic and creative development of preschool children in accordance with the creative-operating criterion

\begin{tabular}{lcccccc}
\hline \multirow{2}{*}{ Markers } & \multicolumn{6}{c}{ Levels } \\
\cline { 2 - 7 } & \multicolumn{2}{c}{$\begin{array}{c}\text { Low } \\
\text { (EG/CG })\end{array}$} & \multicolumn{2}{c}{$\begin{array}{c}\text { Mid } \\
\text { (EG/CG })\end{array}$} & \multicolumn{2}{c}{$\begin{array}{c}\text { High } \\
\text { (EG/CG) }\end{array}$} \\
\cline { 2 - 7 } & $\%$ & $\%$ & $\%$ & $\%$ & $\%$ \\
\hline $\begin{array}{l}\text { Artistic and crea- } \\
\text { tive operating }\end{array}$ & 18.1 & 36.1 & 65.1 & 54.2 & 16.8 & 9.7 \\
\hline $\begin{array}{l}\text { Artistic and crea- } \\
\text { tive activity }\end{array}$ & 13.2 & 16.7 & 65.2 & 68.9 & 21.6 & 14.4 \\
\hline $\begin{array}{l}\text { Generalized } \\
\text { indicator }\end{array}$ & 8.5 & 17.4 & 64.1 & 59.8 & 27.4 & 22.8 \\
\hline
\end{tabular}

The results of the research in accordance with the criteria for the development of artistic and creative abilities are presented in Chart 4.

Chart 4. Levels of artistic and creative development of children of the senior preschool age according to the results of the control test

\begin{tabular}{lcccccc}
\hline \multirow{2}{*}{ Criteria } & \multicolumn{7}{c}{ Levels } \\
\cline { 2 - 7 } & \multicolumn{2}{c}{$\begin{array}{c}\text { Low } \\
\text { (EG/CG) }\end{array}$} & \multicolumn{2}{c}{$\begin{array}{c}\text { Mid } \\
\text { (EG/CG) }\end{array}$} & \multicolumn{2}{c}{$\begin{array}{c}\text { High } \\
\text { (EG/CG) }\end{array}$} \\
\cline { 2 - 7 } & $\%$ & $\%$ & $\%$ & $\%$ & $\%$ \\
\hline $\begin{array}{l}\text { Emotional and } \\
\text { axiological }\end{array}$ & 8.95 & 24.4 & 66.1 & 56.3 & 25.9 & 19.3 \\
\hline $\begin{array}{l}\text { Cognitive-associ- } \\
\text { ative }\end{array}$ & 11.4 & 32.5 & 65.6 & 55.7 & 23.3 & 12.0 \\
\hline $\begin{array}{l}\text { Creative- } \\
\text {-operating }\end{array}$ & 8.5 & 17.4 & 64.1 & 59.8 & 27.4 & 22.8 \\
\hline $\begin{array}{l}\text { Generalized } \\
\text { indicator }\end{array}$ & 9.4 & 34.7 & 65.2 & 52.3 & 25.4 & 13.0 \\
\hline
\end{tabular}


Analysis of the research results showed that the preschool children from the experimental group revealed a positive dynamics of the state of artistic and creative development. In particular, the quality changes recorded in expanding the artistic interests of the preschool children and shaping their emotional and axiological attitude to art, which was characterized by "objectification": the children explained their own emotional experiences on the basis of the understanding of the aesthetic values and acquired artistic knowledge and skills (particularly, with the use of art associations). These positive changes signaled the expansion and enrichment of the artistic perception of the preschool children. The children from the experimental group revealed a formation of artistic and creative skills: they chose their own means of expression of one of the arts to embody the artistic image; demonstrated the ability to translate the artistic image and one artistic language into another. The preschoolers from the EG revealed a stronger desire, compared to the children from the CG, to express themselves in different kinds of artistic and creative activities.

Statistical analysis was performed to get more exact conclusions obtained during the forming stage of the experiment. In order to find out the existence of a significant difference in the results of the experimental and control groups, i.e., the effect of the developed method and not under the influence of random factors, the criterion of Pearson's chi-squared test was used. Initial data were taken at the beginning and end of the experiment in the experimental and control groups.

Analysis of calculations according to the emotional-axiological criterion showed that there is no probable change in the preschoolers from the CG in the control test of the forming stage compared to the final stage $\left(\chi^{2}=0.18\right)$. At the same time, probable changes were detected in the preschoolers from the EG $(\chi 2=19.22)$.

Analysis of the cognitive-associative criterion calculation at the stage of the experiment did not reveal a probable difference between the control and experimental groups $\left(\chi^{2}=0.09\right)$. At the same time, a probable difference in the control test was found for both the CG and the EG. Positive probable changes occurred in the frame of the CG compared with the final stage $\left(\chi^{2}=11.31\right)$ and within the frame of the EG compared with the final stage $\left(\chi^{2}=59.61\right)$. Effectiveness of isolated pedagogical conditions and methodological aspects of the use of art in working with preschoolers is confirmed by the probable difference between the CG and the EG in the control section $(\chi 2=24.73)$.

Similar conclusions can be drawn on the results of calculations according to the creative-operating criterion. At the final stage of the experiment, there was no significant difference between the control and experimental groups $\left(\chi^{2}=0.0051\right)$. After the control test, the probable difference was detected for both the CG and 
the EG. Positive probabilistic changes occurred in the frame of the CG compared with the final stage $(\chi 2=69.77)$ and within the frame of the EG compared with the final stage $(\chi 2=103.37)$.

Comparison of the generalized indicator of artistic and creative development of the preschool children from the CG and the EG between the confirmatory and forming stages of experiment showed the following: at the stage of the investigation - the probable difference between the CG and the EG was not revealed ( $\chi 2$ $=0.0039$ ), in the control test of the forming stage of the experiment, the probable difference was detected as for the CG, and for the EG. Positive probable changes occurred in the frame of the CG compared to the final stage $\left(\chi^{2}=16.07\right)$ and within the frame of the EG compared with the final stage $\left(\chi^{2}=54.31\right)$. Thus, we can conclude that the traditional system of education and the proposed, we have a positive impact on the level of artistic and creative development of children. But the effectiveness of pedagogical conditions and methods of artistic and creative development of preschool children is confirmed by the probable difference between the CG and the EG in the control test of the forming stage of the experiment $\left(\chi^{2}=14.14\right)$.

\section{Conclusions}

Qualitative and quantitative analysis of the results of experimental work, their statistical processing confirmed the effectiveness of the developed pedagogical conditions and methodological aspects of the artistic and creative development of preschoolers by means of art. In view of the above, in order to solve problems of the development of the artistic and creative abilities of preschool children by means of art, it is necessary to adhere to the following pedagogical conditions: orientation of the educational process to children's acquisition of artistic and aesthetic values of art, actualization of the educational potential of works of art in the process of the child's artistic and creative activity, involvement of preschoolers in various types of artistic and creative activity, ensuring the purposeful and systematic influence of works of art on the formation of intellectual, emotional and axiological components of the child's consciousness.

\section{References:}

Bal, M. (1999), Quoting Caravaggio: Contemporary Art, Preposterous History. Cambridge University Press, Cambridge 
Bruner, J.S. (1973). The Conditions of Creativity, [in:] Bruner, J.S., Beyond the Information Given. Studies in the Psychology of Knowing, W.W. Norton \& Co Inc, New York.

Georgsdottir, A. \& Lubart, T.I., (2003). La flexibilité cognitive et la créativité. Psychologie française, 48(3).

Krasoń, K. (2016). The Educational Significance of Art - a Report from Experimental Research. The New Educational Review.

Krasoń, K., Konieczna-Nowak, L. (2016). Sztuka - terapia - poznanie. W stronę podejścia indywidualizujacego $w$ badaniach muzykoterapeutycznych [Art - therapy - cognition. Towards the individualizing approach in music therapy research], Wydawnictwo Naukowe PWN, Warszawa

Nikolopoulou, K., \& Gialamas, V. (2015). ICT and play in preschool: early childhood teachers' beliefs and confidence. International Journal of Early Years Education. 23 (4), 409-425. doi: 10.1080/09669760.2015.1078727. 